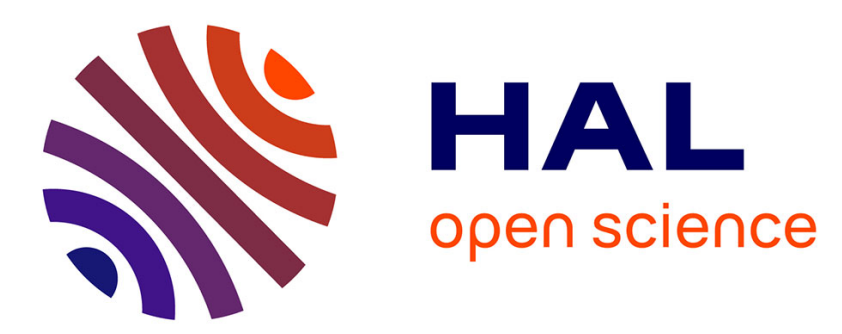

\title{
Comment on 'Ecotoxicity of copper input and accumulation for soil biodiversity in vineyards' by Karimi et al. (2021)
}

Gwenael Imfeld, Joëlle Duplay, Sylvain Payraudeau

\section{To cite this version:}

Gwenael Imfeld, Joëlle Duplay, Sylvain Payraudeau. Comment on 'Ecotoxicity of copper input and accumulation for soil biodiversity in vineyards' by Karimi et al. (2021). Environmental Chemistry Letters, 2021, 19 (5), pp.3525-3527. 10.1007/s10311-021-01259-y · hal-03378931

\section{HAL Id: hal-03378931 \\ https://hal.science/hal-03378931}

Submitted on 15 Oct 2021

HAL is a multi-disciplinary open access archive for the deposit and dissemination of scientific research documents, whether they are published or not. The documents may come from teaching and research institutions in France or abroad, or from public or private research centers.
L'archive ouverte pluridisciplinaire HAL, est destinée au dépôt et à la diffusion de documents scientifiques de niveau recherche, publiés ou non, émanant des établissements d'enseignement et de recherche français ou étrangers, des laboratoires publics ou privés. 


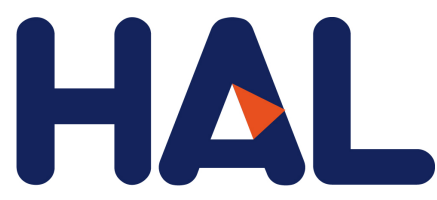

archives-ouvertes

\section{Comment on 'Ecotoxicity of copper input and accumulation for soil biodiversity in vineyards' by Karimi et al. (2021)}

Gwenael Imfeld, Joëlle Duplay, Sylvain Payraudeau

\section{To cite this version:}

Gwenael Imfeld, Joëlle Duplay, Sylvain Payraudeau. Comment on 'Ecotoxicity of copper input and accumulation for soil biodiversity in vineyards' by Karimi et al. (2021). Environmental Chemistry Letters, Springer Verlag, 2021, 19 (5), pp.3525-3527. 10.1007/s10311-021-01259-y • hal-03378931

\section{HAL Id: hal-03378931 \\ https://hal.archives-ouvertes.fr/hal-03378931}

Submitted on 15 Oct 2021

HAL is a multi-disciplinary open access archive for the deposit and dissemination of scientific research documents, whether they are published or not. The documents may come from teaching and research institutions in France or abroad, or from public or private research centers.
L'archive ouverte pluridisciplinaire HAL, est destinée au dépôt et à la diffusion de documents scientifiques de niveau recherche, publiés ou non, émanant des établissements d'enseignement et de recherche français ou étrangers, des laboratoires publics ou privés. 


\title{
Comment on 'Ecotoxicity of copper input and accumulation for soil biodiversity in vineyards' by Karimi et al. (2021)
}

\author{
Gwenaël Imfeld ${ }^{1}$ Joëlle Duplay ${ }^{1}$ S Sylvain Payraudeau ${ }^{1}$
}

Ecotoxicity studies of vineyard soils usually evaluate the effect of addition of a specific dose of copper $(\mathrm{Cu})$. However, soil characteristics and the dynamics of $\mathrm{Cu}$ storage should also be considered to determine at the vineyard and -regional scales ecotoxicity thresholds for soil biological quality.

Karimi and coauthors recently wrote an enlightening review on $\mathrm{Cu}$ ecotoxicity on soil biodiversity in vineyards using results from a literature review (Karimi et al. 2021). This is particularly welcome in a context where wine growers, and in particular organic farmers, are confronted with the absence of efficient alternative to $\mathrm{Cu}$ against downy mildew and the future possibility of a $\mathrm{Cu}$ ban (Andrivon et al. 2018). The vine professional community is experiencing great pressure linked to the historical legacy of the $\mathrm{Cu}$ use, the fast evolution of regulations and climate change. To face this challenging interplay, novel paradigms and integrative approaches are urgently needed, throughout Europe, but taking local specificities into account, to meet the requirements of sustainable viticulture. Only this may help prevent an inexorable increase of $\mathrm{Cu}$ in soils through its systematic and massive use.

Karimi and coauthors reach the conclusion that the currently authorized dose for grape production in the EU, i.e., a maximum of $28 \mathrm{~kg} \mathrm{Cu} \mathrm{ha}^{-1}$ over 7 years, has no deleterious effects on soil organisms. They also compare the average annual dose of $4 \mathrm{~kg} \mathrm{Cu} \mathrm{ha}^{-1} \mathrm{a}^{-1}$ to a Cu ecotoxicity threshold of $200 \mathrm{~kg} \mathrm{Cu} \mathrm{ha}^{-1} \mathrm{a}^{-1}$ defined from a thorough meta-analysis of available data. Although this threshold may be conservative, such a dose specification is, in our view, insufficient to guarantee the integrity of soil fertility and biodiversity.

Gwenaël Imfeld

imfeld@unistra.fr

1 Institut Terre et Environnement de Strasbourg (ITES)/ Earth and Environment Strasbourg (EES), Université de Strasbourg/EOST/ENGEES, CNRS UMR 7063, 5 rue Descartes, F-67084 Strasbourg Cedex, France
We believe that, if accepted, such a view may hamper current efforts to reduce the use of $\mathrm{Cu}$ and attempts to develop locally-accepted alternatives to $\mathrm{Cu}$. Indeed, $\mathrm{Cu}$ storage and availability in the soil prior to the addition of a new dose of $\mathrm{Cu}$ may strongly vary at the vineyard scale and across Europe depending on soil physicochemical properties, the vegetation and the various pools of $\mathrm{Cu}$ formed in soil. The $\mathrm{Cu}$ speciation varying according to soil conditions challenges the notion of harmless use of $\mathrm{Cu}$ at a specific dose, albeit lower than typical historical applications. We define $\mathrm{Cu}$ speciation as the identification and quantification of the different $\mathrm{Cu}$ species, forms or defined phases in which $\mathrm{Cu}$ is present in the soil. Cu speciation depends on the mineralogy and chemistry of the soil.

As emphasized by Karimi and coauthors, historical accumulation of $\mathrm{Cu}$ has already resulted in levels above the defined $\mathrm{Cu}$ ecotoxicity threshold of $200 \mathrm{~kg} \mathrm{Cu} \mathrm{ha}^{-1}$ in some European vineyard soils. This implies to consider not only local risks associated with the historical use of $\mathrm{Cu}$, including soil $\mathrm{pH}$, vegetation, redox or organic matter content, but also risks of present and future use of $\mathrm{Cu}$ in agriculture. Recognizing such historical and present risks is not only necessary, it also affords an opportunity to stimulate studies and innovation for sustainable viticulture. In our view, it is urgently needed to define locally toxicity risks for organisms and integrative approaches of cultivation practice to limit $\mathrm{Cu}$ accumulation (Cesco et al. 2021). Considering the distribution of $\mathrm{Cu}$ concentration by types of land use, vineyards represent the type of land use with the highest proportion (14.6\%) of soil samples with $\mathrm{Cu}$ levels above $100 \mathrm{mg} \mathrm{kg}^{-1}$ (Ballabio et al. 2018). Every $\mathrm{Cu}$ input to the soil contributes to gradual accumulation in the vineyard soil since $\mathrm{Cu}$ does not degrade and $\mathrm{Cu}$ export at the European scale is two orders of magnitude less than the net accumulation of $\mathrm{Cu}$. Considering to use $4 \mathrm{~kg} \mathrm{Cu} \mathrm{ha}^{-1} \mathrm{a}^{-1}$ simply means that the $\mathrm{Cu}$ ecotoxicological threshold for soil biological quality may be reached within 25 years in many vineyards across Europe. 
Thus, $\mathrm{Cu}$ accumulation in soil poses a practical and immediate agricultural and environmental threat at the European scale because the $\mathrm{Cu}$ ecotoxicological threshold for soil biological quality may be reached in the coming decades, thereby challenging vineyard sustainability. In conventional viticulture, the risk of $\mathrm{Cu}$ exposure and toxicity in soil and related aquatic ecosystems combined with that of synthetic organic fungicides has not received much attention. Moreover, it is unclear whether the restriction to a maximum application rate of $28 \mathrm{~kg} \mathrm{Cu} \mathrm{ha}^{-1}$ over seven years will be sufficient to address this issue over time. In a recent study, we showed that the $\mathrm{Cu}$ concentration in vineyard soils is on average $>30 \%$ higher than geogenic and atmospheric non-agricultural anthropogenic $\mathrm{Cu}$ (Droz et al. 2021). We estimate that the threshold of $100 \mathrm{mg} \mathrm{Cu} \mathrm{kg}^{-1}$ (about $150-250 \mathrm{~kg} \mathrm{Cu} \mathrm{ha}^{-1}$ in the top 10-15 $\mathrm{cm}$ layer of soil) has already been exceeded for about $70 \%$ of the vineyard areas in central Western Europe. This proportion will increase in the next decades. Thus, it is necessary to predict $\mathrm{Cu}$ accumulation in vineyard soil across Europe considering the local risks and history of $\mathrm{Cu}$ use. In the future, the proportion of European vineyard area exceeding the predicted no-effect concentration (PNEC) values, typically ranging from 30 to $290 \mathrm{mg} \mathrm{Cu} \mathrm{kg}^{-1}$ depending on soil properties, may vary widely depending on the $\mathrm{Cu}$ dose (Droz et al. 2021). Assuming constant soil properties, the use of 8,4 or $2 \mathrm{~kg} \mathrm{Cu} \mathrm{ha}^{-1} \mathrm{a}^{-1}$ is expected to increase, respectively, by at least $94 \%, 2 \%$ or $0.5 \%$ the proportion of vineyard areas exceeding the PNEC in the next 100 years. These predictions support the idea that $\mathrm{Cu}$ use according to current EU regulation, i.e. $28 \mathrm{~kg} \mathrm{Cu} \mathrm{ha}^{-1} \mathrm{a}^{-1}$ over 7 years, may substantially reduce the ecotoxicological impact of $\mathrm{Cu}$ in the European vineyards compared to historical application doses. However, it also emphasizes that the level of environmental risk for soil biological quality may be substantial at some locations, and also increase in the next decades.

$\mathrm{Cu}$ is partly immobilized in soil with various $\mathrm{Cu}$ pools coexisting and evolving over space and time. It is thus crucial to consider $\mathrm{Cu}$ speciation and its subsequent bioavailability as well as the factors controlling it, in order to evaluate its ecotoxicological impact on soil biological quality. Ecotoxicological studies are often carried out without the consideration of the chemical and physical distribution of historical $\mathrm{Cu}$ among soil fractions, especially in vegetated soil (Ruyters et al. 2013). The pool of $\mathrm{Cu}$ stored in the soil is not an inert, non-reactive mass as opposed to a labile, reactive and potentially harmful input of freshly applied $\mathrm{Cu}$ (e.g., Tom-Petersen et al. 2004). For instance, availability and associated toxicity of $\mathrm{Cu}$ increase with decreasing soil $\mathrm{pH}$, especially at $\mathrm{pH}$ below 5.5. Although soil organic matter rapidly immobilizes $\mathrm{Cu}$, the diffusion of freshly applied $\mathrm{Cu}$ into soil metal oxides, clay minerals and precipitated carbonates is slow and gradual (Lock and Janssen 2003). This results in different chemical fractions of $\mathrm{Cu}$ in the soil that can be mobilized depending on hydro-climatic and soil conditions. Hence, retention processes and availability of aged $\mathrm{Cu}$ in the soil components are dynamic and vary according to the type of soil.

The availability and mobility of $\mathrm{Cu}$ in soil also depend on the vegetation. The $\mathrm{Cu}$ biogeochemical cycle in the soil-plant system diverges from that of the non-rooted bulk soil (Shabbir et al. 2020). Root-induced changes of the $\mathrm{pH}$ and rhizosphere organic compounds in annual grass and perennial plants like grapevine control the $\mathrm{Cu}$ speciation and the formation of soluble organometallic complexes in the soil, altering the potential of $\mathrm{Cu}$ toxicity (Brunetto et al. 2016). In addition, long-term impacts of repeated application of $\mathrm{Cu}$ on both taxonomic and functional diversity of macro- and micro-organisms of vineyard soils require more detailed studies of the dynamics of the $\mathrm{Cu}$ availability and dissemination of $\mathrm{Cu}$ resistance determinants by horizontal gene transfer. Crucially, recurrent intra- and inter-annual application of $\mathrm{Cu}$ to vineyard soil may promote both $\mathrm{Cu}$ and antibiotic resistance, because these two traits are intimately related and can be transferred across the bacterial domain (Cesco et al. 2021). Hence, it cannot be excluded that current use of $\mathrm{Cu}$ in vineyards contributes to development and dissemination of the concomitant $\mathrm{Cu}$ - and antibiotic-resistance via cross-resistance mechanisms.

Altogether, the use of $\mathrm{Cu}$ up to $28 \mathrm{~kg} \mathrm{Cu} \mathrm{ha}^{-1}$ over seven years according to current regulation can significantly reduce the detrimental impact of $\mathrm{Cu}$ on human health and ecosystem diversity. However, it may not always imply an improvement of the quality and sustainability of grape production across Europe. The variability in content, aging and mobility of historical $\mathrm{Cu}$ accumulated in soil should be carefully evaluated at the vineyard and the regional scales. This will allow to define the local use and assess the impact of $\mathrm{Cu}$ more specifically to shape holistic approaches to reduce the $\mathrm{Cu}$ toxicity and consider the trajectory of $\mathrm{Cu}$ accumulation in soil. Despite the scientific interest of the review by Karimi and coauthors, and the fact that it proposes numerous research avenues to respond to the lack of scientific knowledge on the impact of $\mathrm{Cu}$ in wine-growing soils, there is a risk that some of the conclusions are relayed to the agricultural world without integrating the nuances mentioned here. This motivates the present comments.

Acknowledgements We gratefully acknowledge Prof. Stéphane Vuilleumier and Dr. Richard H. Coupe for enabling significant improvement of the comment.

\section{Declaration}

Conflict of interest The authors declare no conflict of interest. The funders had no role in the writing of the manuscript or in the decision to publish this commentary note. 


\section{References}

Andrivon D, Bardin M, Bertrand C et al (2018) Can organic agriculture give up copper as a crop protection product? Condensed report of the Scientific collective assessment, INRA, $66 \mathrm{p}$. https://www. inrae.fr/sites/default/files/pdf/expertise-cuivre-en-ab-8-pagesanglais-1.pdf

Ballabio C, Panagos P, Lugato E et al (2018) Copper distribution in European topsoils: an assessment based on LUCAS soil survey. Sci Total Environ 636:282-298. https://doi.org/10.1016/j.scito tenv.2018.04.268

Brunetto G, Bastos de Melo GW, Terzano R et al (2016) Copper accumulation in vineyard soils: rhizosphere processes and agronomic practices to limit its toxicity. Chemosphere 162:293-307. https:// doi.org/10.1016/j.chemosphere.2016.07.104

Cesco S, Pii Y, Borruso L et al (2021) A smart and sustainable future for viticulture is rooted in soil: how to face Cu toxicity. Appl Sc 11(3):907. https://doi.org/10.3390/app11030907

Droz B, Payraudeau S, Rodriguez-Martin J, Tóth G et al (2021) Copper content and export in European vineyards soils influenced by climate and soil properties. Environ Sci Technol. 55(11):7327-7334. https://doi.org/10.1021/acs.est.0c02093

Karimi B, Masson V, Guilland C et al (2021) Ecotoxicity of copper input and accumulation for soil biodiversity in vineyards.
Environ Chem Lett 19:2013-2030. https://doi.org/10.1007/ s10311-020-01155-x

Lock K, Janssen CR (2003) Influence of aging on metal availability in soils. In: Ware GW (ed) Reviews of environmental contamination and toxicology. Springer, New York, pp 1-21

Ruyters S, Salaets P, Oorts K, Smolders E (2013) Copper toxicity in soils under established vineyards in Europe: a survey. Sci Total Environ 443:470-477. https://doi.org/10.1016/j.scitotenv.2012. 11.001

Shabbir Z, Sardar A, Shabbir A et al (2020) Copper uptake, essentiality, toxicity, detoxification and risk assessment in soil-plant environment. Chemosphere 259:127436. https://doi.org/10.1016/j.chemo sphere.2020.127436

Tom-Petersen A, Hansen HCB, Nybroe O (2004) Time and moisture effects on total and bioavailable copper in soil water extracts. J Environ Qual 33:505-512. https://doi.org/10.2134/jeq2004.5050

Publisher's Note Springer Nature remains neutral with regard to jurisdictional claims in published maps and institutional affiliations. 